\title{
Mycosphere Essays 5: Is it important to name species of Botryosphaeriaceae?
}

\section{Chethana KWT ${ }^{1,2}$, Phillips $\mathrm{AJL}^{3}$, Zhang $\mathrm{W}^{1}$, Chen $\mathrm{Z}^{1}$, Hao $\mathrm{YY}^{4}$, Hyde $\mathrm{KD}^{2}$, Li $\mathbf{X H}^{1, *}$ and Yan JY ${ }^{1, *}$}

\author{
${ }^{1}$ Institute of Plant and Environment Protection, Beijing Academy of Agriculture and Forestry Sciences, Beijing \\ 100097, People's Republic of China \\ ${ }^{2}$ Center of Excellence in Fungal Research and School of Science, Mae Fah Luang University, Chiang Rai 57100, \\ Thailand \\ ${ }^{3}$ University of Lisbon, Faculty of Sciences, Bio systems and Integrative Sciences Institute (BioISI), Campo Grande, \\ 1749-016 Lisbon, Portugal \\ ${ }^{4}$ The Yellow River Delta Sustainable Development Institute of Shandong Province, Dongying 257091, People's \\ Republic of China
}

Chethana KWT, Phillips AJL, Zhang W, Chen Z, Hao YY, Hyde KD, Li XH, Yan JY 2016 Mycosphere Essays 5: Is it important to name species of Botryosphaeriaceae?. Mycosphere 7(7), 870-882, Doi 10.5943/mycosphere/si/1b/3

\begin{abstract}
Botryosphaeriaceae is species rich family comprising numerous plant pathogens and endophytes. Due to their importance, many studies have focused on this family and as a result, the family, genera and species are relatively well defined. Plant pathologists as well as workers involved in the agricultural and forestry sections rely heavily on accurate information concerning species. Scientific names are the primary means of communication concerning these fungal taxa. Names are linked to information such as their biology, ecological niches, distribution, possible threats and even control measures. Hence, naming Botryosphaeriacae species is of utmost importance.
\end{abstract}

Key words - cryptic species - disease control - nomenclature - one name - quarantine

\section{Introduction}

The family Botryosphaeriaceae was introduced by Theissen and Sydow (1918) with the type genus Botryosphaeria Ces. \& De Not. classified in the order Botryosphaeriales C.L. Schoch, Crous \& Shoemaker (1963), Dothideomycetes (Ascomycota) (Schoch et al. 2006, Hyde et al. 2013, 2014, Phillips et al. 2013). Species in this family are cosmopolitan and occur on a wide range of substrates, such as on woody branches, herbaceous leaves, stems and culms of grasses and on twigs of wide range of hosts (monocotyledons, dicotyledons and gymnosperms) and in the thalli of lichens (Barr 1987, Denman et al. 2000, Crous et al. 2006, Mohali et al. 2007, Lazzizera et al. 2008, Marincowitz et al. 2008, Hyde et al. 2013, 2014). Botryosphaeriaceous species are widespread in tropical and temperate regions with a broad range of habits from saprobic to pathogenic or endophytic (Smith et al. 1996, Denman et al. 2000, Burgess et al. 2001, Flowers et al. 2001, Phillips et al. 2006, Slippers \& Wingfield 2007, González \& Tello 2011, Hyde et al. 2013, 2014, Jami et al. 2014). Most of the species are endophytes in healthy hosts for extended periods of 
time (Hawksworth et al. 1995, Smith et al. 1996, Slippers \& Wingfield 2007, Sakalidis 2011, Yan et al. 2013), however when induced by environmental factors or when the vigor of plants is reduced, these roles as endophytes and pathogens tend to overlap, resulting in diseases (Swart \& Wingfield 1991, Slippers \& Wingfield 2007, Bihon et al. 2011, Slippers et al. 2013). All species are plant associated and many cause diseases on a wide range of ecologically and economically important plants in forestry and agriculture (van Niekerk et al. 2004, Mehl et al. 2011, Hyde et al. 2013, 2014, Slippers et al. 2013). They are frequently associated with diseases such as dieback, cankers, shoot blights, leaf spots, fruit and seed rots and witches' brooms (Denman et al. 2000, van Niekerk et al. 2004, Úrbez-Torres 2011, Phillips et al. 2013). There have also been reports of some of the botryosphaeriaceous species causing opportunistic infections in humans (de Hoog et al. 2000).

With well-defined morphology and support from molecular data, various new sexual and asexual genera have been introduced in the family, some older genera have been redefined and some have been transferred to other families during the past decade (Burgess et al. 2005, Phillips et al. 2005, 2008, Crous et al. 2006, Schoch et al. 2009, Liu et al. 2012, Wijayawardene et al. 2012, Hyde et al. 2013, 2014). Emergence of the hidden phylogenetic diversity using DNA-based sequence analyses have made significant changes in the nomenclature and circumscription of botryosphaeriaceous species (Hyde et al. 2013, 2014, Slippers et al. 2013). Currently Botryosphaeriaceae comprises Alanphillipsia Crous \& M.J. Wingf., Barriopsis A.J.L. Phillips, A. Alves \& Crous, Botryobambusa R. Phookamsak, J.K. Liu \& K.D. Hyde, Botryosphaeria, Cophinforma Doilom, J.K. Liu \& K.D. Hyde, Diplodia Fr., Dothiorella Sacc., Endomelanconiopsis E.I. Rojas \& Samuels, Eutiarosporella Crous, Lasiodiplodia Ellis \& Everh., Macrophomina Petr., Marasasiomycyes Crous, Mucoharknessia Crous, R.M. Sánchez \& Bianchin., Neodeightonia C. Booth, Neofusicoccum Crous, Slippers \& A.J.L. Phillips, Neoscytalidium Crous \& Slippers, Phaeobotryon Theiss. \& Syd., Pseudofusicoccum Mohali, Slippers \& M.J. Wingf., Sakireeta Subram. \& K. Ramakr., Spencermartinsia A.J.L. Phillips, A. Alves \& Crous, Sphaeropsis Sacc. and Tiarosporella Höhn (Hyde et al. 2013, 2014, Slippers et al. 2013, Crous et al. 2015a). Due to their ecological and economical significance and with their cryptic nature as endophytes, these fungi are an important group of fungal pathogens (Desprez-Loustau et al. 2006, Dakin et al. 2010, Piškur et al. 2011, Slippers et al. 2013). Hence a significant amount of research has focused on this group, leading to a large knowledge base for the family.

Whenever we want to discuss fungi, communication is always based on their names. During the last two decades, huge amounts of information on fungi have been discovered by the application of various morphological and molecular techniques in fungal taxonomy and systematics (Costello et al. 2013). This accumulated knowledge has been linked to scientific names. Hence the expression of this knowledge and access to it depends heavily on the names. Before the adoption of the binomial nomenclature by Linnaeus in 1753 (Minnis 2015), many nomenclatural practices were used from medieval times for naming a fungus (Lepp 2013, Minnis 2015). With an increasing amount of research focusing on taxonomy, in nineteenth century there was an apparent need for a set of international rules to govern scientific nomenclature. Multiple attempts were made to bring more applicable practices, which resulted in various sets of rules such as the International Code for Botanical Nomenclature (ICBN), which was published by international botanical congress in Vienna (1905) and informally known as Vienna rules. It is amended every six years and the latest revision took place at Melbourne in 2011 (Melbourne Code) where the code name was changed to International Code of Nomenclature for algae, fungi and plants (ICN) to reflect their independence from botanical nomenclature (Hawksworth 2011, Minnis 2015). During the latest revision, a milestone was marked in fungal nomenclature, with the introduction of one name-one fungus concept (McNeil et al. 2012, Gams 2013, Wijayawardene et al. 2014). The latest revision (Hawksworth 2011) eliminates the separate nomenclatural status for naming asexual and sexual morphs of the same fungus, which was required by article 59 of ICBN (McNeil et al. 2006, Gams 2013). 
As mentioned previously, due to the great importance attached to this family in research and pathogenicity of species towards a wide range of hosts, identification and correct naming of the species is crucial. Therefore this review highlights the importance of naming botryosphaeriaceous species, both to the scientific community as well as to the general public.

\section{Importance of naming botryosphaeriaceous species}

\section{Importance of names in species identification and species diversity}

A species name is the initial step in finding and extracting all data available for that species. Morphological and phylogenetic approaches have been used in the identification of Botryosphaeriaceae species (Hyde et al. 2014). Once the species is identified, a name is given, which acts as a reference for its characters during pathogen identification. These names are linked to validated type specimens, reference sequences and cultures, which establish the foundation of the species (Crous et al. 2015b). When a species is identified, it releases the data that have been linked to that name. Hence the pathogen identification lies heavily on the accurate communication on the fungal species using scientific names.

In the case of Botryosphaeriaceae, species identification is complicated by cryptic species. These morphologically identical species differ in their phylogeny, host range, pathogenicity and sometimes in distribution (de Wet et al. 2003, Pavlic et al. 2009). Hence, giving a name to them is important to avoid confusions in subsequent studies. Understanding the diversity of botryosphaeriaceous taxa has also been hindered by the existence of cryptic and closely related species (Sogin et al. 2006, Slippers \& Wingfield 2007). For example, Pavlic et al. (2007) discovered the existence of five cryptic species in the Neofusicoccum parvum (Pennycook \& Samuels) Crous, Slippers \& A.J.L. Phillips/ Neofusicoccum ribis (Slippers, Crous \& M.J. Wingf.) Crous, Slippers \& A.J.L. Phillips complex. Later Pavlic et al. (2009) described and named them as Neofusicoccum cordaticola Pavlic, T.I. Burgess \& M.J. Wingf., Neofusicoccum kwambonambiense Pavlic, T.I. Burgess \& M.J. Wingf. and Neofusicoccum umdonicola Pavlic, T.I. Burgess \& M.J. Wingf. to avoid further confusions. Several other cryptic species complexes have been identified in the genus Neofusicoccum due to their cosmopolitan distribution and sympatric occurrences on a wide variety of hosts such as Neofusicoccum luteum (Pennycook \& Samuels) Crous, Slippers \& A.J.L. Phillips/Neofusicoccum australe Slippers, Crous \& M.J. Wingf.) Crous, Slippers \& A.J.L. Phillip complex (Slippers et al. 2004a, Pavlic et al. 2008) and Neofusicoccum eucalypticola (Slippers, Crous \& M.J. Wingf.) Crous, Slippers \& A.J.L. Phillips/ Neofusicoccum eucalyptorum (Crous, H. Smith \& M.J. Wingf.) Crous, Slippers \& A.J.L. Phillips species complex (Slippers et al. 2004a). Cryptic species have also been identified in the genera Diplodia and Lasiodiplodia namely, Diplodia scrobiculata J. de Wet, Slippers \& M.J. Wingf./ Diplodia sapinea (Fr.) Fuckel (de Wet et al. 2003) species complex and Lasiodiplodia theobromae (Pat.) Griffon \& Maubl. species complex (Alves et al. 2008, Sakalidis 2011). Naming these cryptic species avoids the reintroduction of unnecessary new species, hence, preventing confusion in the taxonomy of the Botryosphaeriaceae taxa. Resolving and naming them also enables the accurate estimation of the diversity within this family.

\section{Importance of names for creating knowledge bases}

Names are essential for communicating information about fungi. Application of molecular techniques in fungal taxonomy and systematics has helped to reveal massive amounts of information on fungi regarding their biology, host range, distribution and potential risk (Costello et al. 2013, Money 2013). Names link this information together and act as access points to the information (Costello et al. 2013). Databases such as MycoBank (http://www.mycobank.org, Crous et al. 2004), Index Fungorum (http://www.indexfungorum.org), Faces of Fungi (Jayasiri et al. 2015) and RefSeq (Schoch et al. 2014) have been developed to store the data on the species and names are the key to access these data. To date, there are about 2670 records for Botryosphaeriacae species in Index Fungorum (Index Fungorum 2016). Among these are records of 
botryosphaeriaceous taxa that have been synonymized under different names or have been transferred to other families. For example, Dothiorella has about 377 records in Index Fungorum, even though only 25 species are currently accepted in the genus (Phillips et al. 2013, Abdollahzadeh et al. 2014, Crous et al. 2015c). However, maintaining all these names in single, easily accessible databases is important for future studies on these pathogens. These databases link scientific names with reference specimens and molecular data. Hence they provide an important source of information on vouchers that assists in fungal identification.

\section{Importance of names in quarantine processes}

Having names for pathogenic species is crucial for quarantine purposes, natural resource management and quality assurance in biological and ecosystem sciences (Costello et al. 2013). Databases such as Q-bank (http://www.q-bank.eu) contain morphological, phenotypical and ecological data for pathogens of quarantine importance (Crous et al. 2015b). Scientific names acts as a key to access information on pathogenic fungi in these databases. Due to the endophytic nature of botryosphaeriaceous taxa, constructing quarantine measures for them is a complicated task (Slippers \& Wingfield 2007, Sakalidis et al. 2011). Even though pathogens like Botryosphaeria dothidea (Moug.) Ces. \& De Not. are listed as quarantine concerns, they are often overlooked due to their endophytic nature (Slippers \& Wingfield 2007). Botryosphaeria stevensii Shoemaker, currently synonymized under Diplodia mutila (Fr.) Mont., is considered a quarantine pathogen in China, as it causes diseases on a range of hosts mainly Acacia Miller, Carya Nutt., Ceratonia L., Eriobotrya Lindl., Fraxinus L., Malus Mill., Prunus L., Pyrus L., Trachycarpus H. Wendl. and Vitis vinifera L. species (Luxi et al. 2015). In addition to these pathogens, there are strict quarantine regulations against several Botryosphaeria species and their anamorphs such as Diplodia sapinea and Lasiodiplodia theobromae in New Zealand and Australia (Burgess \& Wingfield 2002, Hyde et al. 2010). Some Botryosphaeriaceae pathogens such as Neofusicoccum parvum and Diplodia mutila are quarantine concerns in many countries (Lee 2013). In order to take precautions when handling these Botryosphaeriaceae species during quarantine processes, availability of required ecological, morphological and phenotypical data is important. Species names help to acquire correct information for those related processes.

Accurate identification of diseases and the names of their causative agents are important to determine the quarantine importance of the pathogen. For example, Botryosphaeria dothidea was considered as the pathogen of excoriose, a disease widely detected from grapevine growing regions in Europe (Phillips \& Lucas 1997, Phillips 1998, Úrbez-Torres 2011). However, Slippers et al. (2004b) used molecular based techniques to clarify the concept for B. dothidea. As a result it became clear that the pathogen causing excoriose is in fact Neofusicoccum parvum, and not B. dothidea (Úrbez-Torres 2011). Similar confusions were made in the identification of another aggressive pathogen, Neofusicoccum ribis with B. dothidea before the clarification of its' concept. Neofusicoccum ribis causes a variety of stem cankers and fruit rots on a wide range of woody plants (Witcher \& Clayton 1963, English et al. 1975, Maas \& Uecker 1984, Pennycook \& Samuels 1985, Smith et al. 1994, Romero et al. 2005, Slippers et al. 2009, Úrbez-Torres 2011). Multigene phylogeny has facilitated the identification of this pathogen and differentiated it, not only from $B$. dothidea but also from Neofusicoccum parvum, which forms a cryptic species complex with $N$. ribis (Slippers et al. 2009, Crous et al. 2006, Úrbez-Torres 2011, Phillips et al. 2013). Similarly Neofusicoccum luteum (Phillips et al. 2002, Úrbez-Torres 2011) and Neofusicoccum mediterraneum Crous, M.J. Wingf. \& A.J.L. Phillips (Crous et al. 2007, Úrbez-Torres 2011) were also misidentified previously as $B$. dothidea. Hence, correct knowledge of the causal agent facilitates the identification of the disease of quarantine importance.

\section{Importance of names in discovering evolutionary history}

Since the sexual stages are relatively uncommon in nature for the botryosphaeriaceous fungi and inducing them in culture has proven to be difficult, the one name-one fungus approach helps in studies on their taxonomy (Phillips et al. 2013, Wijayawardene et al. 2014). This approach was 
used by Crous et al. (2006), when some Botryosphaeria-like species grouped as distinct genera based on the differences of their anamorphs. They addressed this issue by giving these species the oldest available name, regardless of their sexual or asexual state. Therefore a single genus name accommodated all known morphs of the fungus. Following the one name-one fungus approach, many botryosphaeriaceous taxa names were changed to their anamorphic names or vise versa reflecting their true evolutionary divergences as given in the Table 1. Naming species through this approach assists the thinking and communication regarding the evolutionary history of these botryosphaeriaceous groups (de Wet et al. 2008).

Table 1 Current accepted names and the corresponding old names/synonyms

\begin{tabular}{|c|c|c|}
\hline Current accepted name & Old name / Synonyms & Reference \\
\hline Botryosphaeria & Fusicoccum Corda & Phillips et al. 2013 \\
\hline Phaeobotryosphaeria Speg. & Sphaeropsis & Phillips et al. 2013 \\
\hline Botryosphaeria dothidea & Fusicoccum aesculi Corda & $\begin{array}{l}\text { Slippers et al. } 2004 b \text {, Phillips et } \\
\text { al. } 2013\end{array}$ \\
\hline $\begin{array}{l}\text { Diplodia corticola A.J.L. Phillips, } \\
\text { A. Alves \& J. Luque }\end{array}$ & $\begin{array}{l}\text { Botryosphaeria corticola A.J.L. } \\
\text { Phillips, A. Alves \& J. Luque }\end{array}$ & Phillips et al. 2013 \\
\hline Diplodia mutila & $\begin{array}{l}\text { Botryosphaeria stevensii } \\
\text { Shoemaker }\end{array}$ & Crous et al. 2006 \\
\hline Diplodia seriata De Not. & $\begin{array}{l}\text { Botryosphaeria obtusa (Schwein.) } \\
\text { Shoemaker }\end{array}$ & Phillips et al. 2007 \\
\hline $\begin{array}{l}\text { Dothiorella iberica A.J.L. Phillips, } \\
\text { J. Luque \& A. Alves }\end{array}$ & $\begin{array}{l}\text { Botryosphaeria iberica A.J.L. } \\
\text { Phillips, J. Luque \& A. Alves }\end{array}$ & Phillips et al. 2013 \\
\hline Lasiodiplodia theobromae & $\begin{array}{l}\text { Botryosphaeria rhodina (Berk. \& } \\
\text { M.A. Curtis) Arx }\end{array}$ & Crous et al. 2006 \\
\hline Neofusicoccum australe & $\begin{array}{l}\text { Botryosphaeria australis (Cooke) } \\
\text { Petr. }\end{array}$ & Phillips et al. 2013 \\
\hline Neofusicoccum luteum & $\begin{array}{l}\text { Botryosphaeria lutea A.J.L. } \\
\text { Phillips }\end{array}$ & Phillips et al. 2013 \\
\hline Neofusicoccum parvum & $\begin{array}{l}\text { Botryosphaeria parva Pennycook } \\
\text { \& Samuels }\end{array}$ & Crous et al. 2006 \\
\hline Neofusicoccum ribis & $\begin{array}{l}\text { Botryosphaeria ribis Grossenb. \& } \\
\text { Duggar }\end{array}$ & Slippers et al. 2004b \\
\hline $\begin{array}{l}\text { Spencermartinsia viticola (A.J.L. } \\
\text { Phillips \& J. Luque) A.J.L. Phillips, } \\
\text { A. Alves \& Crous }\end{array}$ & $\begin{array}{l}\text { Dothiorella viticola A.J.L. Phillips } \\
\text { \& J. Luque }\end{array}$ & Phillips et al. 2013 \\
\hline
\end{tabular}

With the application of novel molecular techniques, some previously defined botryosphaeriaceous taxa have been redefined and older genera have been transferred to other families. For example, the genus Phyllosticta Pers. was initially placed in Phyllostictaceae Fr., Phyllostictales (Seaver 1922), which was then transferred to Botryosphaeriaceae to be placed together with its sexual state Guignardia Viala \& Ravaz (Barr 1970, 1972, Schoch et al. 2006, Crous et al. 2006, Liu et al. 2012). With the latest revisions, this genus now lies in its older family Phyllostictaceae, but in Botryosphaeriales (Slippers et al. 2013, Wikee et al. 2013). Similarly, Slippers et al. (2013) transferred the botryosphaeriaceous genera; Saccharata Denman \& Crous, Melanops Nitschke ex Fuckel, Aplosporella Speg. and Bagnisiella Speg. into newly introduced families, Saccharataceae Slippers, Boissin \& Crous, Melanopsaceae Phillips, Slippers, Boissin \& Crous and Aplosporellaceae Slippers, Boissin \& Crous respectively, to reflect their evolutionary origin. Diplodia sapinea also carries a confusing taxonomic history with its name. It was initially described as Sphaeria pinea Desm., then transferred to different genera and synonymized under many names such as Diplodia pinea (Desm.) Kickx (1867), Macrophomina pinea (Desm.) Petrak \& Syd. (1927), Macrophomina sapinea (Fr.) Petrak (1961), Sphaeropsis sapinea and finally named as D. sapinea after many revisions (de Wet 2008, Phillips et al. 2013). Three different morphotypes (A, B and C) of D. sapinea that display differences in their morphology, behaviour and phylogeny 
were differentiated with molecular markers to reflect their evolutionary divergences. (Smith \& Stanosz 1995, Hausner et al. 1999, Burgess et al. 2001, de Wet et al. 2002, 2003, Burgess et al. 2004). In a subsequent study, and to avoid confusions in species identification, the B morphotype of was described as Diplodia scrobiculata while the typical A and C morphotypes were maintained as D. sapinea (de Wet et al. 2002, 2003, Burgess et al. 2004). Similar to D. sapinea, Barriopsis fusca (N.E. Stevens) A.J.L. Phillips, A. Alves \& Crous has also been subjected to revisions and has been accommodated in several families including its initial placement in Physalospora Niessl, then in Phaeobotryon, Botryosphaeria and Phaeobotryosphaeria Speg. (Phillips et al. 2008, Slippers et al. 2013). The nomenclature of Neoscytalidium has undergone many controversies due its morphology. It was initially named as Hendersonula toruloidea Nattrass in Dothideomycetes Incertae sedis and after several revisions it was placed in a new genus Neoscytalidium to show its evolutionary relationship with Botryosphaeriaceae (Crous et al. 2006, Madrida et al. 2009, Phillips et al. 2013). Many previously defined Tiarosporella species have been transferred to Darkera H.S. Whitney, J. Reid \& Piroz. (Phacidiaceae, Phacidiales), Eutiarosporella, Marasasiomycyes, Sakireeta (Subramanian \& Ramakrishnan 1957, Whitney et al. 1975, Roux et al. 1990, Crous et al. 2015a). All these fungal names can acts as chains of well preserved references of communication (Witteveen 2015). Synonymized names under these species provide access points to each and every occurrence of change that has happened to the taxonomy of the species. Morphologically similar but phylogenetically different species were given different names to show their evolutionary divergences such as species belonging to genera Spencermartinsia/Dothiorella, Barriopsis/Lasiodiplodia and Barriopsis/Sphaeropsis (Phillips et al. 2013, Slippers et al. 2013).

\section{Importance of names for farmers and practitioners}

For farmers and crop health practitioners, the most important issue is the protection of plants against diseases. To implement this, accurate information needs to be communicated to the public on the disease-causing pathogens. Names are the keys that unlock details of the biology, distribution, control and the risks associated with the pathogens and they also acts as keys to store and maintain knowledgebases for botryosphaeriaceous taxa, which will be useful for farmers and practitioners to identify diseases at preliminary stages, to prevent possible epidemics as well as to develop new control strategies. For the scientific community, these will provide the foundation for future research on family Botryosphaeriaceae.

Botryosphaeriaceae consists of many well known plant pathogens at cause severe diseases such as Botryosphaeria dothidea, Diplodia seriata, Lasiodiplodia pseudotheobromae A.J.L. Phillips, A. Alves \& Crous, Neofusicoccum parvum and many others (Desprez-Loustau et al. 2006, Dakin et al. 2010, Piškur et al. 2011, Slippers et al. 2013, Hyde et al. 2014). The family also includes some medically important species such as Lasiodiplodia theobromae, Macrophomina phaseolina (Tassi) Goid. and Neoscytalidium dimidiatum (Penz.) Crous \& Slippers and there are some reports on opportunistic fungal infections caused by these pathogens in human (Tan et al. 2008, Woo et al. 2008). Neoscytalidium dimidiatum has been reported as the leading cause of fungal foot disease in Asia, Caribbean, North America, Thailand, West and Central Africa (Levi \& Smith 1994, Ghannoum et al. 2000, Ungpakorn et al. 2005). These medically important botryosphaeriaceous taxa have been recorded as infecting 500 plant species worldwide including economically important crops such as grapes, bean, sorghum, corn and soybean (Holliday \& Punithalingam 1988). Therefore farmers who are working in these agricultural fields need to know about these opportunistic fungal pathogens, so they can handle the pathogens with care. These well known plant pathogens (Crous et al. 2006) infect humans through environmental exposure and contact with diseased plant material and contaminated soil (Tan et al. 2008). When the farmers are aware of the names of these pathogens, they can always take necessary precautions when they are exposed to these pathogens or when their agricultural fields are under the attack from these botryosphaeriaceous pathogens. Therefore, accurate communication on these species is critical. Since this communication occurs via scientific names, naming is of utmost importance to the 
family. Inaccurate communication can cause the spread of potentially devastating pathogens or unnecessary and costly actions (Hawksworth 2015, Crous et al. 2015b).

\section{Conclusions}

Due to the importance of the family Botryosphaeriaceae, which consists of pathogens or latent pathogens of ecologically and economically important plants, names are of utmost importance as the primary medium of communication. Scientific names link these pathogens with their evolutionary history, diversity, distribution and their ecological roles and also act as the keys to interconnect to their information in various databases. These data facilitate the correct identification of the pathogens, detection of the pathogens during quarantine processes and enhances their awareness among the scientific community. Information stored in these databases will provide the platform for future Botryosphaeriaceae research in any field. Since names help in accessing these data, naming of Botryosphaeriaceae is essential.

\section{Acknowledgements}

The project was funded by Beijing Nova Program (Z141105001814047), CARS-30 and KJCX20140402. We are grateful to the Mushroom Research Foundation, Chiang Rai, Thailand. K.D. Hyde thanks the Chinese Academy of Sciences, project number 2013T2S0030, for the award of Visiting Professorship for Senior International Scientists at Kunming Institute of Botany. The authors have no conflict of interest to declare.

\section{References}

Abdollahzadeh J, Javadi A, Zare R, Phillips AJL. 2014 - A phylogenetic study of Dothiorella and Spencermartinsia species associated with woody plants in Iran, New Zealand, Portugal and Spain. Persoonia 32, 1-12.

Alves A, Crous PW, Correia A, Phillips AJL. 2008 - Morphological and molecular data reveal cryptic speciation in Lasiodiplodia theobromae. Fungal Diversity 28, 1-13.

Barr ME. 1970 - Some amerosporous ascomycetes on Ericaceae and Empetraceae. Mycologia 62, 377-394.

Barr ME. 1972 - Preliminary studies on the Dothideales in temperate North America. Contributions from the University of Michigan Herbarium 9, 523-638.

Barr ME. 1987 - Prodromus to class Class Loculoascomycetes. Published by the author, Amherst, Massachusetts, USA.

Bihon W, Burgess T, Slippers B, Wingfield MJ, Wingfield BD. 2011 - Distribution of Diplodia pinea and its genotypic diversity within asymptomatic Pinus patula trees. Australasian Plant Pathology 40, 540-548.

Burgess T, Wingfield MJ. 2002 - Quarantine is important in restricting the spread of exotic seedborne tree pathogens in the southern hemisphere. International Forestry Review 4(1), 5665.

Burgess T, Wingfield BD, Wingfield MJ. 2001 - Comparison of genotypic diversity in native and introduced populations of Sphaeropsis sapinea isolated from Pinus radiata. Mycological Research 105, 1331-1339.

Burgess TI, Gordon TR, Wingfield MJ, Wingfield BD. 2004 - Geographic isolation of Diplodia scrobiculata and its association with native Pinus radiata. Mycological Research 108, 1399-1406.

Burgess TI, Barber PA, Hardy GESJ. 2005 - Botryosphaeria spp. associated with eucalypts in Western Australia including description of Fusicoccum macroclavatum sp. nov.. Australasian Plant Pathology 34, 557-567.

Costello MJ, May RM, Stork NE. 2013 - Can we name Earth's species before they go extinct? Science 339, 413-416. 
Crous PW, Gams W, Stalpers JA, Robert V, Stegehuis G. 2004 - MycoBank: an online initiative to launch mycology into the $21^{\text {st }}$ century. Studies in Mycology 50, 19-22.

Crous PW, Slippers B, Wingfield MJ, Rheeder J, Marasas WFO, Philips AJL, Alves A, Burgess T, Barber P, Groenewald JZ. 2006 - Phylogenetic lineages in the Botryosphaeriaceae. Studies in Mycology 55, 235-253.

Crous PW, Wingfield MJ, Phillips AJL. 2007 - Neofusicoccum mediterraneum sp. nov. Fungal Planet 19, Centraalbureau voor Schimmelculures, Netherlands.

Crous PW, Müller MM, Sánchez RM, Giordano L, Bianchinotti MV, Anderson FE, Groenewald JZ. 2015a - Resolving Tiarosporella spp. allied to Botryosphaeriaceae and Phacidiaceae. Phytotaxa 202(2), 73-93.

Crous PW, Hawksworth DL, Wingfield MJ. 2015b - Identifying and naming plant-pathogenic fungi: past, present and future. Annual Review of Phytopathology 53, 247-267.

Crous PW, Schumacher RK, Wingfield MJ, Lombard L, Giraldo A, Christensen M, Gardiennet A, Nakashima C, Pereira OL, Smith AJ, Groenewald JZ. 2015c - Fungal Systematics and Evolution: FUSE 1. Sydowia 67, 81-118.

Dakin N, White D, Hardy GESJ, Burgess TI. 2010 - The opportunistic pathogen, Neofusicoccum australe, is responsible for crown dieback of peppermint (Agonis flexuosa) in Western Australia. Australasian Plant Pathology 39, 202-206.

de Hoog GS, Guarro J, Gené J, Figueras MJ. 2000 - Atlas of clinical fungi, 2nd ed. Centraalbureau voor Schimmelcultures, Utrecht and Universitat Rovira I Virgili, Reus.

de Wet J. 2008 - Molecular studies on the taxonomy, host-associations and viruses of the Diplodialike anamorphs of the Botryosphaeriaceae. PhD thesis, University of Pretoria, Pretoria.

de Wet J, Wingfield MJ, Coutinho T, Wingfield BD. 2002 - Characterisation of the "C" morphotype of the pine pathogen Sphaeropsis sapinea. Forest Ecology and Management 161, 181-188.

de Wet J, Burgress T, Slippers B, Presig O, Wingfield BD, Wingfield MJ. 2003 - Multiple gene genealogies and microsatellite markers reflect relationships between morphotypes of Sphaeropsis sapinea and identify a new species of Diplodia. Mycological Research 107, 557-566.

de Wet J, Slippers B, Preisig O, Wingfield BD, Wingfield MJ. 2008 - Phylogeny of the Botryosphaeriaceae reveals patterns of host association. Molecular Phylogenetics and Evolution 46, 116-126.

Denman S, Crous PW, Taylor JE, Kang JC, Pascoe I, Wingfield MJ. 2000 - An overview of the taxonomic history of Botryosphaeria, and a re-evaluation of its anamorphs based on morphology and ITS rDNA phylogeny. Studies in Mycology 45, 129-140.

Desprez-Loustau ML, Marcais B, Nageleisen LM, Piou D, Vannini A. 2006 - Interactive effects of drought and pathogens in forest trees. Annals of Forest Science 63, 597-612.

English H, Davis JR, DeVay JE. 1975 - Relationship of Botryosphaeria dothidea and Hendersonula toruloides to a canker disease of almond. Phytopathology 65, 114-122.

Flowers J, Nuckles E, Hartman J, Vaillancourt L. 2001 - Latent infections of Austrian and Scots pine tissues by Sphaeropsis sapinea. Plant Disease 85, 1107-1112.

Gams W. 2013 - A new nomenclature for fungi. Mycologia Iranica 1(1), 5-8.

Ghannoum MA, Hajjeh RA, Scher R, Konnikov N, Gupta AK, Summerbell R. 2000 - A largescale North American study of fungal isolates from nails: The frequency of onychomycosis, fungal distribution, and antifungal susceptibility patterns. Journal of the American Academy of Dermatology 43(4), 641-648.

González V, Tello ML. 2011 - The endophytic mycota associated with Vitis vinifera in central Spain. Fungal Diversity 47(1), 29-42.

Hausner G, Hopkin AA, Davis CN, Reid J. 1999 - Variation in culture and rDNA among isolates of Sphaeropsis sapinea from Ontario and Manitoba. Canadian Journal of Plant Pathology 21, 256-264. 
Hawksworth DL, Kirk PM, Sutton BC, Pegler DN. 1995 - Ainsworth and Bisby's dictionary of the fungi, $8^{\text {th }}$ ed. CAB international, UK.

Hawksworth DL. 2011 - A new dawn for the naming of fungi: impacts of decisions made in Melbourne in July 2011 on the future publication and regulation of fungal names. IMA Fungus 2(2), 155-162.

Hawksworth DL. 2015 - Proposals to clarify and enhance the naming of fungi under the International Code of Nomenclature for algae, fungi and plants. IMA Fungus 6(1), 199-205. Holliday P, Punithalingam E. 1988 - CMI descriptions of pathogenic fungi and bacteria. No. 275.

Hyde KD, Chomnunti P, Crous PW, Groenewald JZ, Damm U, Ko Ko TW, Shivas RG, Summerell BA, Tan YP. 2010 - A case for re-inventory of Australia's plant pathogens. Persoonia 25, $50-60$.

Hyde KD, Jones EBG, Liu JK, Ariyawansha H, Eric B, Boonmee S, Braun U, Chomnunti P, Crous PW, Dai D, Diederich P, Dissanayake A, Doilom M, Doveri F, Hongsanan S, Jayawardena R, Lawrey JD, Li YM, Liu YX, Lücking R, Monkai J, Nelson MP, Phookamsak R, Muggia L, Pang KL, Senanayake I, Shearer CA, Wijayawardene N, Wu HX, Thambugala KM, Suetrong S, Tanaka K, Wikee S, Zhang Y, Aguirre-Hudson B, Alias SA, Aptroot A, Bahkali AH, Bezerra JL, Bhat JD, Binder M, Camporesi E, Chukeatirote E, Hoog SD, Gueidan C, Hawksworth DL, Hirayama K, Kang JC, Knudsen K, Li WJ, Liu AY, Mapook A, Raja HA, Tian Q, Scheuer C, Schumm F, Taylor J, Yacharoen S, Tibpromma S, Wang Y, Yan JY, Zhang M. 2013 - Families of Dothideomycetes. Fungal Diversity 63, 1-313.

Hyde KD, Nilsson RH, Alias SA, Ariyawansa H, Blair JE, Cai L, de Cock AWAM, Dissanayake AJ, Glockling SJ, Goonasekara ID, Gorczak M, Hahn M, Jayawardena RS, van Kan JAL, Laurence MH, Lévesque CA, Li XH, Liu JK, Maharachchikumbura SSN, Manamgoda DS, Martin FN, McKenzie EHC, McTaggart AR, Mortimer PE, Nair PVR, Pawłowska J, Rintoul TL, Shivas RG, Spies CFJ, Summerell BA, Taylor PWJ, Terhem RB, Udayanga D, Vaghefi N, Walther G, Wilk M, Wrzosek M, Xu JC, Yan JY, Zhou N. 2014 - One stop shop: backbones trees for important phytopathogenic genera: I. Fungal Diversity 67, 21125 .

Index Fungorum - 2016. http://www.indexfungorum.org (accessed 2 January 2016).

Jami F, Slippers B, Wingfield MJ, Gryzenhout M. 2014 - Botryosphaeriaceae species overlap on four unrelated, native South African hosts. Fungal Biology 118, 168-179.

Jayasiri SC, Hyde KD, Ariyawansa HA, Bhat J, Buyck B, Cai L, Dai Y-C, Abd-Elsalam KA, Ertz D, Hidayat I, Jeewon R, Jones EBG, Bahkali AH, Karunarathna SC, Liu, Luangsaard JJ, Lumbsch HT, Maharachchikumbura SSN, McKenzie EHC, Moncalvo J-M, Ghobad-Nejhad M, Nilsson H, Pang K-L, Pereira OL, Phillips AJL, Raspé O, Rollins AW, Romero AI, Etayo J, Selçuk F, Stephenson SL, Suetrong S, Taylor JE, Tsui CKM, Vizzini A, AbdelWahab MA, Wen T-C, Boonmee S, Dai DQ, Daranagama DA, Dissanayake AJ, Ekanayaka AH, Fryar SC, Hongsanan S, Jayawardena RS, Li WJ, Perera RH, Phookamsak R, de Silva NI, Thambugala KM, Tian Q, Wijayawardene NN, Zhao RL, Zhao Q, Kang JC, Promputtha I. 2015 - The Faces of Fungi database: fungal names linked with morphology, phylogeny and human impacts. Fungal Diversity 74(1), 3-18.

Lazzizera C, Frisullo S, Alves A, Lopes J, Phillips AJL. 2008 - Phylogeny and morphology of Diplodia species on olives in southern Italy and description of Diplodia olivarum. Fungal Diversity 31, 63-71.

Lee S. 2013 - List of plant quarantine fungi in Korea, Newly revised in 2013. Plant Disease 19(3), 237-241.

Lepp H. 2013 - Classification, names \& identification. Australian National Botanic Gardens and Australian National Herbarium, Canberra. http://www.environment.gov.au/topics/nationalparks/parks-australia (Accessed 4 January 2016).

Levi ME, Smith JW. 1994 - Posttraumatic infection due to Scytalidium dimidiatum. Clinical Infectious Diseases 18, 127-128. 
Liu JK, Phookamsak R, Doilom M, Wikee S, Li YM, Ariyawansa HA, Boonmee S, Chomnunti P, Dai DQ, Bhat JD, Romero AI, Zhuang WY, Monkai J, Jones EBG, Chukeatirote E, Ko TWK, Zhao YC, Wang Y, Hyde KD. 2012 - Towards a natural classification of Botryosphaeriales. Fungal Diversity 57, 149-210.

Luxi Z, Shaoyi S, Binbin J, Zixiang Y, Cui Y, Cuiyun Y. 2015 - Identification of Botryosphaeria stevensii Shoemaker on imported Fraxinus mandshrica logs. Plant Quarantine 29(1), 25-29.

Maas JL, Uecker FA. 1984 - Botryosphaeria dothidea cane canker of thornless blackberry. Plant Disease 68, 720-726.

Madrida H, Ruíz-Cendoyaa M, Canoa J, Stchigel A, Orofinob R, Guarroa J. 2009 - Genotyping and in vitro antifungal susceptibility of Neoscytalidium dimidiatum isolates from different origins. International Journal of Antimicrobial Agents 34, 351-354.

Marincowitz S, Groenewald JZ, Wingfield MJ, Crous PW. 2008 - Species of Botryosphaeriaceae occurring on Proteaceae. Persoonia 21, 111-118.

McNeill J, Barrie FR, Burdet HM, Demoulin V, Hawksworth DL, Marhold K, Nicolson DH, Prado J Silva PC, Skog JE, Wiersema JH, Turland NJ (eds). 2006 - International Code of Botanical Nomenclature (Vienna Code) adopted by the Seventeenth International Botanical Congress Vienna, Austria, July 2005. [Regnum Vegetabile no. 146.] Ruggell: R.G. Ganter Verlag.

McNeill J, Barrie FR. Buck WR, Demoulin V, Greuter W, Hawksworth DL, Herendeen PS, Knapp S, Marhold K, Prado J, Prud'homme van Reine WF, Smith GE, Wiersema JH, Turland NJ. 2012 - International Code of Nomenclature for algae, fungi, and plants (Melbourne Code) adopted by the Eighteenth International Botanical Congress Melbourne, Australia, July 2011. [Regnum Vegetabile no. 154.] Koeltz, Königstein.

Mehl JWM, Slippers B, Roux J, Wingfield MJ. 2011 - Botryosphaeriaceae associated with Pterocarpus angolensis (kiaat) in South Africa. Mycologia 103(3), 534-553.

Minnis AM. 2015 - The Shifting Sands of Fungal Naming Under the ICN and the One Name Era for Fungi. In: Esser K, The Mycota, Comprehensive Treatise on Fungi as Experimental Systems for Basic and Applied Research : Systematics and Evolution Part B, $10^{\text {th }}$ edition, 179-200.

Mohali S, Slippers B, Wingfield MJ. 2007 - Identification of Botryosphaeriaceae from Euclyptus, Acacia and Pinus in Venezuela. Fungal Diversity 25, 103-125.

Money NP. 2013 - Against the naming of fungi. Fungal Biology 117, 463-465.

Pavlic D, Slippers B, Coutinho TA, Wingfield MJ. 2007 - Botryosphaeriaceae occurring on native Syzygium cordatum in South Africa and their potential threat to Eucalyptus. Plant Pathology 56, 624-636.

Pavlic D, Wingfield MJ, Barber P, Slippers B, Harder GES, Burgess TI. 2008 - Seven new species of the Botryosphaeriaceae from baobab and other native trees in Western Australia. Mycologia 100, 851-866.

Pavlic D, Slippers B, Coutinho TA, Wingfield MJ. 2009 - Multiple gene genealogies and phenotypic data reveal cryptic species of the Botryosphaeriaceae: A case study on the Neofusicoccum parvum / N. ribis complex. Molecular Phylogenetics and Evolution 51, 259268.

Pennycook SR, Samuels GJ. 1985 - Botryosphaeria and Fusicoccum species associated with ripe fruit rot of Actinidia deliciosa (kiwifruit) in New Zealand. Mycotaxon 24, 445-458.

Phillips AJL. 1998 - Botryosphaeria dothidea and other fungi associated with excoriose and dieback of grapevines in Portugal. Journal of Phytopathology 146, 327-332.

Phillips AJL, Lucas MT. 1997 - The taxonomic status of Macrophoma flaccida and Macrophoma reniformis and their relationship to Botryosphaeria dothidea. Sydowia 49, 150-159.

Phillips AJL, Fonseca F, Povoa V, Castilho R, Nolasco G. 2002 - A reassessment of the anamorphic fungus Fusicoccum lutem and description of its teleomorph Botryosphaeria lutea sp. nov. Sydowia 54, 59-77. 
Phillips AJL, Alves A, Correia A, Luque J. 2005 - Two new species of Botryosphaeria with brown, 1-septate ascospores and Dothiorella anamorphs. Mycologia 97, 513-529.

Phillips AJL, Oudemans PV, Correia A, Alves A. 2006 - Characterisation and epitypification of Botryosphaeria corticis, the cause of blueberry cane canker. Fungal Diversity 21, 141-155.

Phillips AJL, Crous PW, Alves A. 2007 - Diplodia seriata, the anamorph of "Botryosphaeria" obtusa. Fungal Diversity 25, 141-155.

Phillips AJL, Alves A, Pennycook SR, Johnston PR, Ramaley A, Akulov A, Crous PW. 2008 Resolving the phylogenetic and taxonomic status of dark-spored teleomorph genera in the Botryosphaeriaceae. Persoonia 21, 29-55.

Phillips AJL, Alves A, Abdollahzadeh J, Slippers B, Wingfield MJ, Groenewald JZ, Crous PW. 2013 - The Botryosphaeriaceae: genera and species known from culture. Studies in Mycology 76, 51-167.

Piškur B, Pavlic D, Slippers B, Ogris N, Maresi G, Wingfield MJ, Jurc D. 2011 - Diversity and pathogenicity of Botryosphaeriaceae on declining Ostrya carpinifolia in Slovenia and Italy following extreme weather conditions. European Journal of Forest Research 130(2), 235249.

Romero MA, Sánchez ME, Trapero A. 2005 - First Report of Botryosphaeria ribis as a Branch Dieback Pathogen of Olive Trees in Spain. Plant Disease 89(2), 208-208.

Roux C, Coetzee J, van Warmeloo KT. 1990 - Ontogeny of conidiomata and conidia in Tiarosporella graminis var. karroo. Mycological Research 94, 254-262.

Sakalidis ML. 2011 - Investigation and analysis of taxonomic irregularities within the Botryosphaeriaceae. PhD Thesis, Murdoch University, Perth, Western Australia.

Sakalidis ML. Ray JD, Lanoiselet V, Hardy GESJ, Burgess TI. 2011 - Pathogenic Botryosphaeriaceae associated with Mangifera indica in the Kimberley Region of Western Australia. European Journal of Plant Pathology 130, 379-391.

Schoch CL, Shoemaker RA, Seifert KA, Hambleton S, Spatafora JW, Crous PW. 2006 - A multigene phylogeny of the Dothideomycetes using four nuclear loci. Mycologia 98, 10411052.

Schoch CL, Crous PW, Groenewald JZ, Boehm EWA, Burgess TI, de Gruyter J, de Hoog GS, Dixon LJ, Grube M, Gueidan C, Harada Y, Hatakeyama S, Hirayama K, Hosoya T, Huhndorf SM, Hyde KD, Jones EBG, Kohlmeyer J, Kruys $\AA$, Li YM, Lücking R, Lumbsch HT, Marvanová L, Mbatchou JS, McVay AH, Miller AN, Mugambi GK, Muggia L, Nelsen MP, Nelson P, Owensby CA, Phillips AJL, Phongpaichit S, Pointing SB, Pujade-Renaud V, Raja HA, Plata ER, Robbertse B, Ruibal C, Sakayaroj J, Sano T, Selbmann L, Shearer CA, Shirouzu T, Slippers B, Suetrong S, Tanaka K, Volkmann-Kohlmeyer B, Wingfield MJ, Wood AR, Woudenberg JHC, Yonezawa H, Zhang Y, Spatafora JW. 2009 - A class-wide phylogenetic assessment of Dothideomycetes. Studies in Mycology 64, 1-15.

Schoch CL, Robbertse B, Robert V, Vu D, Cardinali G, Irinyi L, Meyer W, Nilsson RH, Hughes K, Miller AN, Kirk PM, Abarenkov K, Aime MC, Ariyawansa HA, Bidartondo M, Boekhout T, Buyck B, Cai Q, Chen J, Crespo A, Crous PW, Damm U, Beer ZWD, Dentinger BTM, Divakar PK, Dueñ M, Feau N, Fliegerova K, García MA, Ge Z-W, Griffith GW, Groenewald JZ, Groenewald M, Grube M, Gryzenhout M, Gueidan C, Guo L, Hambleton S, Hamelin R, Hansen K, Hofstetter V, Hong S-B, Houbraken J, Hyde KD, Inderbitzin P, Johnston PR, Karunarathna SC, Kõljalg U, Kovács GM, Kraichak E, Krizsan K, Kurtzman CP, Larsson K-H, Leavitt S, Letcher PM, Liimatainen K, Liu J-K, Lodge DJ, Luangsa-ard JJ, Lumbsch HT, Maharachchikumbura SSN, Manamgoda D, Martín MP, Minnis AM, Moncalvo J-M, Mulé G, Nakasone KK, Niskanen T, Olariaga I, Papp T, Petkovits T, PinoBodas R, Powell MJ, Raja HA, Redecker D, Sarmiento-Ramirez JM, Seifert KA, Shrestha B, Stenroos S, Stielow B, Suh S-O, Tanaka K, Tedersoo L, Telleria MT, Udayanga D, Untereiner WA, Uribeondo JD, Subbarao KV, Vágvölgyi C, Visagie C, Voigt K, Walker DM, Weir BS, Wei M, Wijayawardene NN, Wingfield MJ, Xu JP, Yang ZL, Zhang N, 
Zhuang W-Y, Federhen S. 2014 - Finding needles in haystacks: linking scientific names, reference specimens and molecular data for Fungi. Database 2014(6), 336-341.

Seaver FJ. 1922 - Phyllostictaceae. North American Flora 6, 3-84.

Slippers B, Wingfield MJ. 2007 - Botryosphaeriaceae as endophytes and latent pathogens of woody plants: diversity, ecology and impact. Fungal Biology Reviews 21, 90-106.

Slippers B, Fourie G, Crous PW, Coutinho TA, Wingfield BD, Carnegie AJ, Wingfield MJ. 2004a - Speciation and distribution of Botryosphaeria sp. on native and introduced Eucalyptus trees in Australia and South Africa. Studies in Mycology 50, 343-358.

Slippers B, Crous PW, Denman S, Coutinho TA, Wingfield BD, Wingfield MJ. 2004b - Combined multiple gene genealogies and phenotypic characters differentiate several species previously identified as Botryosphaeria dothidea. Mycologia 96, 83-101.

Slippers B, Burgess T, Pavlic D, Ahumada R, Maleme H, Mohali S, Rodas C, Wingfield MJ. 2009 - A diverse assemblage of Botryosphaeriaceae infect Eucalyptus in native and non-native environments. Southern Forests 71(2), 101-110.

Slippers B, Boissin E, Phillips AJL, Groenewald JZ, Lombard L, Wingfield MJ, Postma A, Burgess T, Crous PW. 2013 - Phylogenetic lineages in the Botryosphaeriales: a systematic and evolutionary framework. Studies in Mycology 76, 31-49.

Smith DR, Stanosz GR. 1995 - Confirmation of two distinct populations of Sphaeropsis sapinea in the North Central United States using RAPDs. Phytopathology 85, 699-704.

Smith H, Kemp GHJ, Wingfield MJ. 1994 - Canker and dieback of Eucalyptus in South Africa caused by Botryosphaeria dothidea. Plant Pathology 43, 1031-1034.

Smith H, Wingfield MJ, Petrini O. 1996 - Botryosphaeria dothidea endophytic in Eucalyptus grandis and Eucalyptus nitens in South Africa. Forest Ecology and Management 89, 189195.

Sogin ML, Morrison HG, Huber JA, Mark Welch D, Huse SM, Neal PR, Arrieta JM, Herndl GJ. 2006 - Microbial diversity in the deep sea and the underexplored "rare biosphere". Proceedings of National Academy of Sciences USA 103, 12115-12120.

Subramanian CV, Ramakrishnan K. 1957 - Neottiospora Desm. and two new genera Samukuta and Sakireeta. Journal of the Indian Botanical Society 36, 68-86.

Swart WJ, Wingfield MJ. 1991 - Biology and control of Sphaeropsis sapinea on Pinus species in South Africa. Plant Disease 75, 761-766.

Tan DHS, Sigler L, Gibas CFC, Fong IW. 2008 - Disseminated fungal infection in a renal transplant recipient involving Macrophomina phaseolina and Scytalidium dimidiatum: case report and review of taxonomic changes among medically important members of the Botryosphaeriaceae. Medical Mycology 46, 285-292.

Ungpakorn R. 2005 - Mycoses in Thailand: current concerns. Nippon Ishinkin Gakkai Zasshi 46, $81-86$.

Úrbez-Torres JR. 2011 - The status of Botryosphaeriaceae species infecting grapevines. Phytopathologia Mediterranea 50, S5-S45.

van Niekerk JM, Crous PW, Groenewald JZ, Fourie PH, Halleen F. 2004 - DNA phylogeny, morphology and pathogenicity of Botryosphaeria species on grapevines. Mycologia 96, 781-798.

Whitney HS, Reid J, Pirozynski KA. 1975 - Some new fungi associated with needle blight of conifers. Canadian Journal of Botany 53, 3051-3063.

Wijayawardene DNN, McKenzie EHC, Hyde KD. 2012 - Towards incorporating anamorphic fungi in a natural classification - checklist and notes for 2011. Mycosphere 3(2), 157-228.

Wijayawardene NN, Crous PW, Kirk PM, Hawksworth DL, Boonmee S, Braun U, Chomnunti P, Dai DQ, D'souza MJ, Diederich P, Dissanayake A, Doilom M, Hongsanan S, Jones EBG, Groenewald JZ, Jayawardena R, Lawrey JD, Liu JK, Lücking R, Madrid H, Manamgoda DS, Muggia L, Nelson MP, Phookamsak R, Suetrong S, Tanaka K, Thambugala KM, Wikee S, Zhang Y, Aptroot A, Ariyawansa HA, Bahkali AH, Bhat JD, Gueidan C, De Hoog GS, Knudsen K, McKenzie EHC, Miller AN, Mortimer PE, Wanasinghe DN, Phillips AJL, 
Raja HA, Slippers B, Shivas RS, Taylor JE, Wang Y, Woudenberg JHC, Piatek M, Cai L, Jaklitsch WM, Hyde KD. 2014 - Naming and outline of Dothideomycetes. Fungal Diversity 69(1), 1-55.

Wikee S, Lombard L, Nakashima C, Motohashi K, Chukeatirote E, Cheewangkoon R, McKenzie EHC, Hyde KD, Crous PW. 2013 - A phylogenetic re-evaluation of Phyllosticta (Botryosphaeriales). Studies in Mycology 76, 1-29.

Witcher W, Clayton CN. 1963 - Blueberry stem blight caused by Botryosphaeria dothidea (B. ribis). Phytopathology 53, 705-712.

Witteveen J. 2015 - Naming and contingency: the type method of biological taxonomy. Biology \& Philosophy 30, 569-586.

Woo PCY, Lau SKP, Ngan AHY, Tse H, Tung ETK, Yuen K-Y. 2008 - Lasiodiplodia theobromae pneumonia in a liver transplant recipient. Journal of Clinical Microbiology 46, 380-384.

Yan J, Xie Y, Zhang W, Wang Y, Liu J, Hyde KD, Seem RC, Zhang G, Wang Z, Yao S, Bai X, Dissanayake AJ, Peng Y, Li X. 2013 - Species of Botryosphaeriaceae involved in grapevine dieback in China. Fungal Diversity 61, 221-236. 